\title{
Penerapan Media Video Analisis Gerak terhadap Peningkatan Keterampilan Shooting pada Pemain Sepakbola
}

\author{
Andris Risnanda ${ }^{l}$ Ucup Yusuf ${ }^{l}$ \\ ${ }^{1}$ Pendidikan Kepelatihan Olahraga, Fakultas Pendidikan Olahraga dan Kesehatan, Universitas \\ Pendidikan Indonesia, Bandung, Indonesia \\ *Correspondence: E-mail: risnandaa003@gmail.com
}

\begin{abstract}
A B S T R A C T S
The purpose of this study was to determine the use of motion analysis video media to improve the shooting skills of players. The research method used was an experimental method. The population of this research is the PSBUM UPI soccer player age 13 years totaling 12 players using research sampling with total sampling. This research instrument uses shooting skills test on soccer. The conclusion of this study is that training using motion analysis video media has a significant influence on shooting skills on KU-13-year soccer players. It is recommended to coaches, instructors, soccer coaches and readers to provide motion analysis video media training in order to improve football shooting skills in the implementation of training programs for soccer players aged 13 years.
\end{abstract}

(c) 2019 Tim Pengembang Jurnal Kepelatihan Olahraga

\author{
ARTICLE INFO \\ Article History: \\ Received 23 Nov 2019 \\ Revised 10 Jan 2020 \\ Accepted 30 Jan 2020 \\ Available online 31 March 2020 \\ Keyword: \\ Technology and Information, \\ Audio Visual, Motion Analysis, \\ Shooting Skills, and Football.
}




\section{PENDAHULUAN}

Penelitian ini berangkat dari persoalan yang dilihat oleh peneliti ketika melatih di Sekolah Sepakbola Pembinaan Sepakbola Usia Muda Universitas Pendidikan Indonesia (SSB PSBUM UPI) usia 13 tahun sejak tahun 2018, peneliti banyak menemukan pemain yang ketika mengikuti latihan dan kejuaraan masih menemukan banyak kekurangan, salah satu diantaranya adalah perlakuan shooting dari para pemain yang belum sempurna.

Teknik untuk melatih shooting dapat dilakukan dengan metode drill. Diungkap oleh (Istofian, 2016) bahwa 'peningkatan kemampuan teknik shooting dapat meningkat dengan latihan shooting drill'. Untuk meningkatkan kemampuan shooting harus didukung oleh kemampuan fisik, karna komponen dukungan tersebut memiliki hubungan yang saling memberikan pengaruh terhadap kemampuan melakukan shooting (Saputra, 2015).

Perkembangan saat ini adalah adanya dukungan teknologi dan ilmu pengetahuan berkembang semakin pesat. Kemudahan penyampaian informasi menggunakan media membantu pembelajaran atau pelatihan untuk peserta didik maupun atlet menerima suatu pesan. Menurut Ainina (2014) 'Dalam suatu proses komunikasi memiliki tiga komponen pokok, diantaranya; komponen pengirim pesan (pelatih), komponen penerima pesan (Atlet) dan komponen pesan itu sendiri yang berisi materi-materi'.

Menurut Ameliola (2013) "bukanlah suatu hal yang baru, teknologi merupakan salah satu bagian yang mendukung peradaban kebudayaan manusia. Revolusi industri telah menjembatani teknologi modern bisa berkebang saat ini,
Perkembangan teknologi di sisi lain ternyata memberikan dampak yang sebelumnya tidak pernah dibayangkan manusia". Penjelasan tersebut membenarkan apa yang sudah dirasakan dan terjadi banyak perubahan dari setiap adanya teknologi dan informasi.

Dampak kemajuan media informasi dan teknologi memang telah dirasakan oleh hampir seluruh masyarakat, baik positif maupun negatif dari penggunaan. Penggunaan media informasi ini tergolong mudah dan terjangkau untuk berbagai kalangan, baik untuk kaula muda maupun tua. pemanfaatan media informasi atau alat menyampaikan pesan ini bisa melalui tulisan, Audio, Visual, bahkan gabungan dari setiap unsur seperti pada video.

Penting dilakukannya observasi oleh peneliti ketika melatih di klub sepakbola ternyata banyak pemain ketika latihan shooting terlihat kurang tertarik atau terlihat malas-malasan. Berangkat dari hal tersebutlah peneliti mengintegrasikan kemajuan teknologi terutama pemanfaatan media melalui video untuk membantu keterampilan melakukan shooting cabang olahraga sepakbola.

\section{METODE}

Metode penelitian ini adalah true eksperimental dengan menggunakan desain pretest-posttest control group. Teknik pengambilan sampel dilakukan dengan total sampling sehingga secara keseluruhan menjadi objek untuk diteliti. Instrumen yang sesuai untuk digunakan adalah tes keterampilan shooting di cabang olahraga sepakbola. Sumber Nurhasan dan Cholil (2007) dengan validitas 0,69 dan reliabilitas tes 0,82 . 


\subsection{Subjek Penelitian}

Populasi dalam penelitian ini adalah siswa sekolah sepakbola PSBUM UPI usia 13 tahun Bandung yang berjumlah 12 siswa. Sampel yang peneliti gunakan berjumlah 12 pemain SSB PSBUM UPI usia 13 tahun. Alasan mengambil total sampling karena jumlah siswa SSB PSBUM UPI usia 13 sebanyak 12 orang.

\subsection{Prosedur Penelitian}

Penelitian dilakukan terhadap siswa Sekolah Sepakbola PS BUM UPI di Bandung Provinsi Jawa Barat. Pelaksanaan penelitian dilakukan di lapang Sepakbola FPOK UPI selama 16 kali pertemuan. Frekuensi latihan 3 kali seminggu dengan jumlah pertemuan keseluruhan adalah 16 kali. Pertemuan pertama digunakan untuk pengarahan, perkenalan, dan pembagian kelompok. 16 kali perlakuan eksperimen, dan satu kali pertemuan terakhir untuk tes keterampilan shooting sepakbola.

Penelitian ini melibatkan satu variabel bebas yang dimanipulasi yaitu media video analisis gerak. Sedangkan variabel terikatnya adalah keterampilan shooting bermain sepakbola. Unit-unit eksperimen dikelompokkan ke dalam sel sehingga unit-unit eksperimen relatif homogen. Agar rancangan penelitian yang dilaksanakan dapat memenuhi persyaratan untuk pengujian hipotesis, dan hasilnya dapat mencerminkan perlakuan yang diberikan, serta dapat digeneralisasikan ke populasi yang ada. Oleh karena itu, dalam penelitian ini dilakukan pengontrolan terhadap validitas internal dan validitas eksternal. Dengan desain penelitian yang digunakan adalah eksperimen pretest-posttest control group design.

\section{HASIL PENELITIAN}

Pengujian hipotesis penelitian dilakukan dengan analisis uji pengaruh. Selanjutnya, untuk mengetahui perbedaan keterampilan shooting bermain sepakbola diantara kelompok eksperimen dan kelompok kontrol yang diberi perlakuan berbeda dilakukan analisis dengan media video analisis gerak. Data hasil penelitian disajikan pada Grafikl 1.1. sebagai berikut.

Grafik 1.1. Rata-rata selisih skor tes awal dan tes akhir tes keterampilan shooting kelompok eksperimen.

\section{Kelompok Eksperimen}

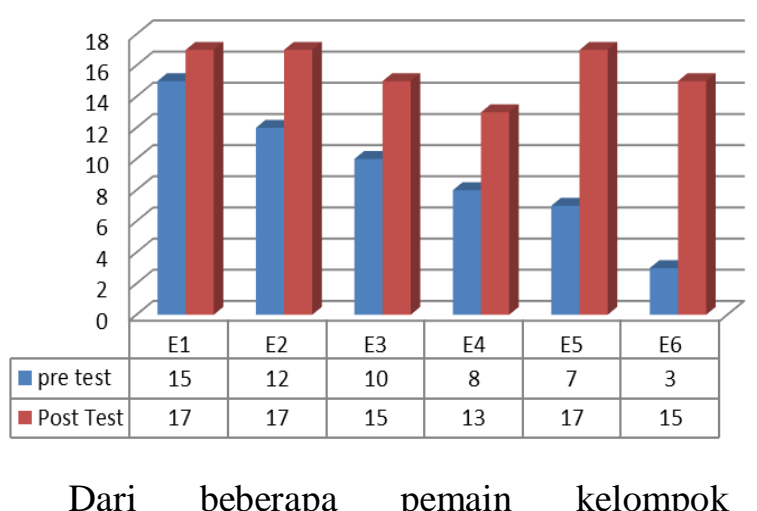

eksperimen ada pemain yang meningkat secara signifikan yaitu E5. Gambaran data tersebut menunjukkan adanya peningkatan dimana dalam setiap latihan pemain ini banyak melakukan progress yang positif karena dilihat dari latihan berlangsung, sangat baik, serta mengikuti materi ajar yang diberikan dari awal, pemain ini banyak peningkatan tiap latihan berlangsung. Grafik 1. 1 berwarna biru adalah data tes yang dilakukan pada saat pertama kali dengan tujuan ingin mengetahui kemampuan awal yang dijadikan gain dengan hasil grafik merah. Berikutnya Lihat Grafik 1.2. 
Grafik 1.2. Rata-rata selisih skor tes awal dan tes akhir tes keterampilan shooting kelompok kontrol

\section{Kelompok Kontrol}

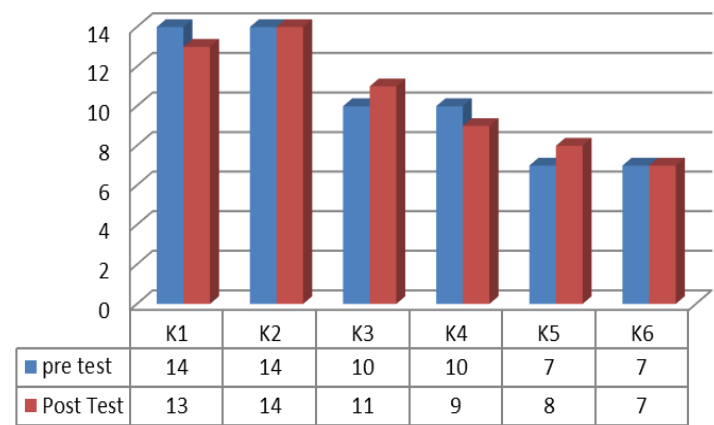

Dari kelompok kontrol, peneliti menemukan pemain yang menurun yaitu $\mathrm{K} 1$. Dilihat dari latihannya K1 tidak begitu baik dalam melakukan materi latihan shooting yang dijelaskan oleh peneliti dilapangan, dan Raivan juga tidak begitu baik dalam mempraktekan materinya. Peneliti melihat K1 ketika diberikan video tidak begitu memperhatikan walaupun sudah ditegur. Hasil analisis data yang dilakukan dengan menggunakan uji-t yang disajikan pada Tabel 1.1 sebagai berikut.

Tabel 1.1. Hasil Data Penelitian Uji-t

\begin{tabular}{lcccc}
\hline \multicolumn{1}{c}{ Source } & $d f$ & $\begin{array}{c}\text { Mean } \\
\text { difference }\end{array}$ & $F$ & Sig \\
\hline $\begin{array}{l}\text { t-test for } \\
\text { Equality of } \\
\text { Means }\end{array}$ & 10 & & 3.214 & .002 \\
& & & & \\
\end{tabular}

Dilihat dari Tabel 1.1 output uji independent samples test antara posttest kelompok eksperimen dengan posttest kelompok kontrol di ketahui nilai Sig.(2-tailed) 0,002 lebih kecil dari 0,05 , sesuai dengan pedoman pengambilan keputusan yang telah dipaparkan di atas maka Ho ditolak dan Ha diterima, yang berarti Terdapat perbedaan rata-rata hasil shooting antara posttest kelompok eksperimen dengan kelompok kontrol.

\section{PEMBAHASAN}

Pengaruh media video analisis gerak terhadap peningkatan keterampilan shooting pada pemain sepakbola di SSB PSBUM ku -13 tahun diperoleh hasil pengolahan data di atas bahwa penelitian shooting menggunakan media video analisis gerak memberikan pengaruh yang signifikan terhadap peningkatan keterampilan shooting pada pemain sepakbola di SSB PSBUM ku-13 tahun. Perlu diketahui bahwa shooting adalah teknik dasar dalam cabang sepakbola. Menurut Achmad Hafid Hilmi (2017) menyatakan bahwa terdapat pengaruh setelah diberikan treatment dengan menggunakan audio visual.

Media secara umum adalah alat bantu proses belajar mengajar. Sedangkan menurut Briggs (1977) media pembelajaran adalah sarana fisik untuk menyampaikan isi materi pembelajaran seperti; buku, film, video dan sebagainya kemudian. Menurut Lonergan, (1970) mengungkapkan bahwa 'media pembelajaran adalah sarana komunikasi dalam bentuk cetak maupun pandang- dengar, termasuk teknologi perangkat keras. Media yang digunakan dalam penelitian ini adalah media audio visual atau video.

Video sebagai media pembelajaran adalah suatu media yang dirancang secara sistematis dengan berpedoman kepada kurikulum yang berlaku pengembangannya mengaplikasikan prinsip-prinsip pembelajaran atau pelatihan sehingga program tersebut memungkinkan peserta didik atau atlet mencermati materi pelatihan secara mudah, menarik dan dapat dipahami. 


\section{KESIMPULAN DAN SARAN}

Berdasarkan hasil penelitian, perhitungan, dan analisis data penelitian yang telah dilakukan, mengenai pengaruh media video analisis gerak terhadap paningkatan keterampilan shooting, maka dapat ditarik kesimpulan bahwa latihan dengan menggunakan media video analisis gerak memberikan pengaruh yang signifikan terhadap keterampilan shooting pada pemain sepakbola di SSB PSBUM ku13 tahun. Peneliti berharap hasil dari penelitian ini bisa dijadikan sebagai pengetahuan tambahan dan referensi bagi para pelatih untuk dapat diterapkan dan membantu meningkatkan keterampilan kepada pemain yang kurang baik dalam melakukan keterampilan shooting.

\section{DAFTAR PUSTAKA}

Ainina, I. A. (2014). Pemanfaatan media audio visual sebagai sumber pembelajaran. Indonesian journal of history education, 3(1).

Ameliola, S., \& Nugraha, H. D. (2013, June). Perkembangan media informasi dan teknologi terhadap anak dalam era globalisasi. In Prosiding In International Conference On Indonesian Studies" Ethnicity And Globalization.

Briggs, Leslie J. 1997. Instructional Design, Educational Technology Publications Inc. New Jersey: Englewood Cliffs.

Hafid Hilmi, A. C. H. M. A. D. (2017). Penerapan Audio Visual terhadap Hasil Shooting pada Permainan Futsal (Studi Penelitian Pada Peserta Ekstrakurikuler Futsal SMA Negeri 1 Krembung Sidoarjo). Jurnal Pendidikan Olahraga dan Kesehatan, 4(2).

Nurhasan \& Cholil, H. (2007). Tes dan Pengukuran Keolahragaan. Bandung: FPOK-UPI.

Istofian, R. S., \& Amiq, F. (2016). Metode Drill untuk Meningkatkan Teknik Menendang Bola (Shooting) dalam Permainan Sepakbola Usia 13-14 Tahun. Jurnal Kepelatihan Olahraga, 1(1).

Lonergan, B. D. (1970). Education Directory: Education Associations 1969-1970.

Saputra, W. D., Ramadi, R., \& Juita, A. (2015). Hubungan Kekuatan Otot Tungkai Dan Kecepatan Terhadap Kemampuan Shooting Dalam Permainan Sepakbola Pada SSB Universitas Riau U-15 (Doctoral dissertation, Riau University). 